\title{
The Glucose-Dependent Insulinotropic Polypeptide Receptor: A Novel Target for Neuroendocrine Tumor Imaging-First Preclinical Studies
}

\author{
Eleni Gourni ${ }^{1-3}$, Beatrice Waser ${ }^{4}$, Pascal Clerc ${ }^{5}$, Daniel Fourmy ${ }^{5}$, Jean Claude Reubi ${ }^{4}$, and Helmut R. Maecke ${ }^{2}$ \\ ${ }^{I}$ German Cancer Consortium (DKTK), Heidelberg, Germany; ${ }^{2}$ Department of Nuclear Medicine, University Hospital Freiburg, \\ Freiburg, Germany; ${ }^{3}$ German Cancer Research Center (DKFZ), Heidelberg, Germany; ${ }^{4}$ Department of Pathology, University \\ Hospital Bern, Bern, Switzerland; and Institut de la Santé et de la Recherche Médicale, Toulouse, France
}

A new family of peptide receptors, the incretin receptor family, overexpressed on many neuroendocrine tumors (NETs) is of great importance because it may enable the in vivo peptide-based receptor targeting of a category of NETs that does not express the somatostatin receptor. Impressive in vivo diagnostic data were published for glucagonlike peptide 1 receptor-targeting radiopeptides. Recently, promising in vitro data have appeared for the second member of the incretin family, the glucose-dependent insulinotropic polypeptide (GIP) receptor. This prompted us to develop and evaluate a new class of radioligands with the potential to be used for the in vivo targeting of GIP receptor-positive tumors. Methods: GIP(1-42) was modified C-terminally, and the truncated peptides [ Lys $^{30}$ (aminohexanoic acid [Ahx]-DOTA)]GIP(1-30) $\mathrm{NH}_{2}$ (EG1), [Lys ${ }^{16}($ Ahx-DOTA)]GIP (1-30) $\mathrm{NH}_{2}$ (EG2), and [Nle ${ }^{14}$, Lys ${ }^{30}\left(\right.$ Ahx-DOTA)]GIP(1-30) $\mathrm{NH}_{2}$ (EG4) were conjugated with Ahx-DOTA via the Lys ${ }^{16}$ and Lys ${ }^{30}$ side chains. Their inhibitory concentration of $50 \%\left(\mathrm{IC}_{50}\right)$ was determined using [ ${ }^{125} \mid-$ $\left.\mathrm{Tyr}^{10}\right] \mathrm{GIP}(1-30)$ as radioligand and $\mathrm{GIP}(1-30)$ as control peptide. The DOTA conjugates were labeled with ${ }^{111}$ In and ${ }^{68} \mathrm{Ga}$. In vitro evaluation included saturation and internalization studies using the pancreatic endocrine cell line INR1G9 transfected with the human GIP receptor (INR1G9-hGIPr). The in vivo evaluation consisted of biodistribution and PET imaging studies on nude mice bearing INR1G9hGIPr tumors. Results: Binding studies ( $\mathrm{IC}_{50}$ and saturation studies) showed high affinity toward GIP receptor for the GIP conjugates. Specific in vitro internalization was found, and almost the entire cellassociated activity was internalized $(>90 \%$ of the cell-bound activity), supporting the agonist potency of the ${ }^{111}$ In-vectors. ${ }^{111}$ In-EG4 and ${ }^{68} \mathrm{Ga}-\mathrm{EG} 4$ were shown to specifically target INR1G9-hGIPr xenografts, with tumor uptake of $10.4 \% \pm 2.2 \%$ and $17.0 \% \pm 4.4 \%$ injected activity/g, $1 \mathrm{~h}$ after injection, respectively. Kidneys showed the highest uptake, which could be reduced by approximately $40 \%-$ $50 \%$ with a modified-fluid-gelatin plasma substitute or an inhibitor of the serine protease dipeptidyl peptidase 4 . The PET images clearly visualized the tumor. Conclusion: The evaluation of EG4 as a proof-ofprinciple radioligand indicated the feasibility of imaging GIP receptorpositive tumors. These results prompt us to continue the development of this family of radioligands for imaging of a broad spectrum of NETs.

Received Oct. 10, 2013; revision accepted Feb. 5, 2014.

For correspondence or reprints contact: Helmut Maecke, University Hospital Freiburg, Department of Nuclear Medicine, Hugstetter Strasse 55, 79106 Freiburg, Germany.

E-mail: helmut.maecke@uniklinik-freiburg.de

Published online Apr. 17, 2014.

COPYRIGHT $\odot 2014$ by the Society of Nuclear Medicine and Molecular Imaging, Inc.
Key Words: glucose-dependent insulinotropic polypeptide receptor (GIPr); neuroendocrine tumors (NETs); ${ }^{111} \mathrm{In} ;{ }^{68} \mathrm{Ga}$; imaging

J Nucl Med 2014; 55:976-982

DOI: 10.2967/jnumed.113.133744

$\mathbf{T}$ he regulatory peptides and their receptors have gained an important role in the targeted imaging and radionuclide therapy of cancer over the last few decades. Overexpression of the receptors on the surface of cancer cells, in combination with their considerably low expression in surrounding healthy tissues, is the key to successful application of these methods in the field of nuclear medicine $(1,2)$.

The somatostatin receptor was the first to be defined for in vivo targeting. The overexpression of somatostatin receptor on neuroendocrine tumors (NETs) has allowed tumor localization, staging, therapy follow-up, and targeted radionuclide therapy (3). Radiolabeled somatostatin analogs can be used to localize NETs with high specificity and sensitivity, translating into successful targeted radionuclide therapy or to PET imaging (4-7). Although the overexpression of somatostatin has proven to be an important tool for the targeting of NETs, there are limitations since not all NETs express somatostatin (8). Therefore, the identification of other families of receptors that would enable the in vivo targeting of those tumors is of high importance (9). A new and promising family of G-proteincoupled receptors is the incretin receptor family $(8,10,11)$. The imaging of tumors overexpressing the glucagonlike peptide 1 (GLP-1) receptor was proven to be successful in insulinoma preclinically $(12-17)$ and clinically $(18,19)$. Recently, it was found that the second member of the incretin receptor family, the glucose-dependent insulinotropic polypeptide (GIP) receptor, is overexpressed in specific NETs. Most somatostatin-negative NETs ( 90\%) and GLP-1 receptor-negative malignant insulinomas are GIP receptor-positive (20).

GIP is a 42-amino-acid polypeptide synthesized by $\mathrm{K}$ cells of the duodenum and small intestine. Like its sister incretin hormone GLP-1, GIP is secreted by the intestine, causing a glucose-dependent release of insulin from the $\beta$ cells and inhibition of glucagon from the $\alpha$ cells $(21,22)$. GIP is rapidly inactivated to GIP(3-42) by the widespread serine protease dipeptidyl peptidase (DPP) 4 , with a plasma half-life of approximately 5-7 $\min (23,24)$. The intact $\mathrm{N}$-terminal and parts of the first 30 amino acids are necessary for biologic activity and binding to the GIP receptor-binding pocket with high affinity (25-27). GIP receptor belongs to the subfamily B1 of the $\mathrm{G}$ protein-coupled receptor superfamily, specifically the 
glucagon receptor family, and is expressed in low density throughout the human body $(22,25)$. In pathologic conditions, GIP receptor is overexpressed in functional (such as insulinomas and gastrinomas) and nonfunctional pancreatic, ileal, and bronchial NETs. Malignant insulinomas are an interesting case of cancer since they all seem to preserve GIP receptor expression while seldom expressing somatostatin and GLP-1 receptors. The high expression of GIP receptor in these cases of NETs, in contrast to the low physiologic expression as proven by autoradiographic studies and messenger RNA analysis, may lead to high tumor-to-background ratios and fulfill the prerequisite for successful in vivo peptide receptor targeting (20).

In this study, we developed and evaluated a new class of GIPbased radioligands with the potential to image a broad spectrum of NETs. Three GIP-based radioligands, $\left[\right.$ Lys $^{30}$ (aminohexanoic acid [Ahx]-DOTA)] GIP(1-30) $\mathrm{NH}_{2}$ (EG1), [Lys ${ }^{16}$ (Ahx-DOTA)]GIP(130) $\mathrm{NH}_{2}$ (EG2), and $\left[\mathrm{Nle}^{14}, \mathrm{Lys}^{30}\right.$ (Ahx-DOTA)]GIP(1-30)NH $\mathrm{NH}_{2}$ (EG), were developed and labeled with ${ }^{68} \mathrm{Ga}$ and ${ }^{111} \mathrm{In}$. In vitro evaluation included determination of inhibitory concentration of $50 \%$ $\left(\mathrm{IC}_{50}\right)$, dissociation constant $\left(\mathrm{K}_{\mathrm{d}}\right)$, and maximum number of binding sites $\left(\mathrm{B}_{\max }\right)$, along with internalization studies using the pancreatic endocrine cell line INR1G9 transfected with the human GIP receptor (INR1G9-hGIPr). With the most promising candidate, EG4, we extended the in vivo evaluation to biodistribution and PET studies in INR1G9-hGIPr xenografts.

\section{MATERIALS AND METHODS}

The supplier information for all reagents and details of instruments used are provided in the supplemental data (supplemental materials are available at http://jnm.snmjournals.org).

\section{Radiolabeling with ${ }^{111}$ In and ${ }^{68} \mathrm{Ga}$}

The radioligands were prepared as described in detail in the supplemental data. Briefly, ${ }^{111}$ In-conjugates were prepared by dissolving $20 \mu \mathrm{g}(5 \mathrm{nmol})$ of peptide in $250 \mu \mathrm{L}$ of ammonium acetate buffer $(0.5 \mathrm{~mol} / \mathrm{L}, \mathrm{pH} 5.4)$, followed by incubation with ${ }^{111} \mathrm{InCl}_{3}(35-40$ $\mathrm{MBq}$ ) for $30 \mathrm{~min}$ at $95^{\circ} \mathrm{C}$. After the labeling with ${ }^{111} \mathrm{In}$, one equivalent of nat $\mathrm{InCl}_{3} \times 2 \mathrm{H}_{2} \mathrm{O}$ was added and the final solution was incubated again at $95^{\circ} \mathrm{C}$ for $30 \mathrm{~min}$ to obtain structurally characterized homogeneous ligands, which were used for the saturation binding studies. ${ }^{68} \mathrm{Ga}$-conjugates were prepared within $10 \mathrm{~min}$ at $95^{\circ} \mathrm{C}$ starting with 40 $\mu \mathrm{g}$ of the conjugates, followed by purification using the Modular-Lab PharmTracer module (Eckert and Ziegler).

\section{Cell Line}

Hamster glucagon-secreting pancreatic cells (INR1G9) kindly given by Prof. Jacques Philippe, University of Geneva, Switzerland, were transfected with pcDNA3 vector containing human cDNA encoding short variant of the human GIP receptor using lipofectamine.
Selected clones were screened by fluorescence-activated call sorter analysis of binding of fluorescent tagged GIP(1-30) (Alexa Fluor 647 dye; Life Technologies), as previously described (25). The INR1G9-hGIPr cells were cultured at $37^{\circ} \mathrm{C}$ and $5 \% \mathrm{CO}_{2}$ in Dulbecco modified Eagle medium containing fetal bovine serum (10\%), penicillin $(100 \mathrm{U} / \mathrm{mL})$, streptomycin $(100 \mu \mathrm{g} / \mathrm{mL})$, and the antibiotic G418 $(500 \mu \mathrm{g} / \mathrm{mL})$ for the selection of the stably transfected cells.

\section{Determination of Binding Affinity}

The binding affinity profiles ( $\mathrm{IC}_{50}$ values) of EG1, EG2, EG4, and GIP(1-30) were determined by in vitro GIP receptor autoradiography on cryostat sections of human insulinoma tissue as described previously (20). The radioligand used was $\left[{ }^{125} \mathrm{I}-\mathrm{Tyr}^{10}\right] \mathrm{GIP}(1-30)(74,000 \mathrm{GBq}$ $[2,000 \mathrm{Ci}] / \mathrm{mmol}$ ) (Anava) $(20,25)$.

\section{Saturation Binding and Internalization Studies}

INR1G9-hGIPr cells were seeded at a density of $0.8-1$ million cells per well in 6-well plates and incubated with increasing concentrations of either ${ }^{111 / n a t I n-E G 2}$ or ${ }^{111 / n a t I n-E G 4 ~(1-100 ~ n M) ~ f o r ~}$ saturation binding studies. For internalization studies, approximately 2.5 pmol of the respective radiopeptide were added to the cell medium followed by incubation for $0.5,1,2,4$, and $6 \mathrm{~h}$ at $37^{\circ} \mathrm{C}$, $5 \% \mathrm{CO}_{2}$. Both procedures are described in detail in the supplemental data.

\section{Animal Model}

Female athymic nude mice (age, 4-6 wk; weight, 17-20 g) were purchased from Janvier. For implantation, the cells were harvested by trypsinization and $5 \times 10^{6}$ cells in $100 \mu \mathrm{L}$ of phosphate-buffered saline were inoculated subcutaneously into the right shoulder of the mice. After an average of 2-3 wk, tumors reached 80-100 mg and the animals were used for biodistribution and PET studies. All animal experiments were approved by local authorities and were in compliance with institutional guidelines.

\section{Biodistribution and Renal Uptake Reduction Studies}

Ten picomoles/0.03-0.04 MBq of ${ }^{111} \mathrm{In}-\mathrm{EG} 4$ and ${ }^{68} \mathrm{Ga}-\mathrm{EG} 4$ in 100 $\mu \mathrm{L}$ of $\mathrm{NaCl} 0.9 \%$ were injected into the tail vein of INR1G9-hGIPr xenografts. Animals were sacrificed by isoflurane anesthesia at 1, 4, and $24 \mathrm{~h}$ after injection in the case of ${ }^{111} \mathrm{In}-\mathrm{EG} 4$ and at 1 and $2 \mathrm{~h}$ after injection in the case of ${ }^{68} \mathrm{Ga}-\mathrm{EG} 4$.

Three groups of mice ( $n=4$ /group) were intravenously administered $100 \mu \mathrm{L}$ of a modified-fluid-gelatin plasma substitute (Gelofusine; B. Braun) $(40 \mathrm{mg} / \mathrm{mL})$, were orally administered $150 \mu \mathrm{L}(10$ $\mu \mathrm{mol} / \mathrm{kg}$ ) of the DPP-4 inhibitor vildagliptin (Galvus [Novartis], 50 $\mathrm{mg}$ ) dissolved in water, or were given the combination of the two. Gelofusine was administered just before and vildagliptin $1 \mathrm{~h}$ before intravenous injection of $10 \mathrm{pmol}$ of the radiotracer. One hour later, the mice were sacrificed. Finally, radioactivity uptake in organs and tumors was calculated as percentage injected activity (\%IA)/g.

TABLE 1

Analytic Data Along with $\mathrm{IC}_{50}$ Values of Conjugates

\begin{tabular}{lcccccc}
\hline Compound & Elemental composition & Purity & $\begin{array}{c}\text { Calculated monoisotopic } \\
\text { mass: } m / z\left([M+H]^{+}\right)\end{array}$ & $\begin{array}{c}M S(M A L D I): ~ \\
m / z\left([M+H]^{+}\right)\end{array}$ & $R t(m i n)$ & $I C_{50}(n M)$ \\
\hline GIP(1-30) & $\mathrm{C}_{162} \mathrm{H}_{241} \mathrm{~N}_{40} \mathrm{O}_{47} \mathrm{~S}_{1}$ & $>95 \%$ & $3,530.742$ & $3,531.424$ & 15.0 \\
EG1 & $\mathrm{C}_{184} \mathrm{H}_{278} \mathrm{~N}_{45} \mathrm{O}_{55} \mathrm{~S}_{1}$ & $>95 \%$ & $4,030.006$ & $4,031.219$ & 15.4 & $2.1 \pm 1.0$ \\
EG2 & $\mathrm{C}_{184} \mathrm{H}_{278} \mathrm{~N}_{45} \mathrm{O}_{55} \mathrm{~S}_{1}$ & $>95 \%$ & $4,030.006$ & $4,031.334$ & 15.3 & $2.5 \pm 0.8$ \\
EG4 & $\mathrm{C}_{185} \mathrm{H}_{280} \mathrm{~N}_{45} \mathrm{O}_{55}$ & $>95 \%$ & $4,012.049$ & $4,012.552$ & 15.0 & $1.5 \pm 0.7$
\end{tabular}

MS = mass spectrometry; MALDI = matrix-assisted laser desorption/ionization; $\mathrm{Rt}=$ retention time. 

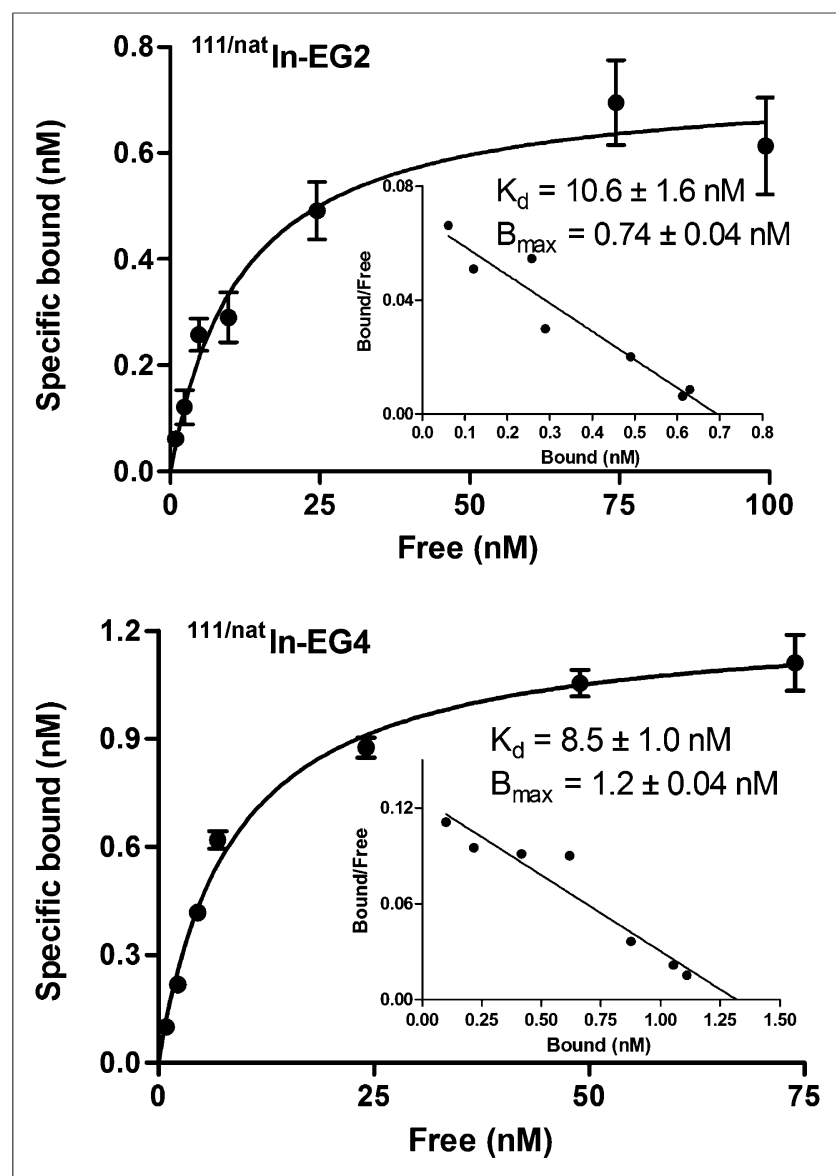

FIGURE 1. Saturation binding study on intact INR1G9-hGIPr cells,

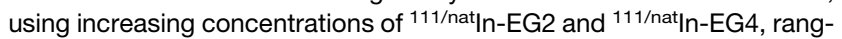
ing from 0.1 to $1,000 \mathrm{nM}$. $K_{d}$ and $B_{\max }$ were calculated from nonlinear regression analysis using Prism 5 software.

Biodistribution studies were conducted as described in detail in the supplemental data.

\section{Small-Animal PET Studies}

The mice were divided into 2 groups ( $n=2 /$ group). The mice of the first group were injected with $100 \mathrm{pmol} / 0.6-0.8 \mathrm{MBq} / 100 \mu \mathrm{L}$ of ${ }^{68} \mathrm{Ga}-$ $\mathrm{EG} 4$, and dynamic imaging was performed with the following acquisition frames: $30 \times 10,10 \times 30,6 \times 600,10 \times 60,10 \times 120$, and $4 \times$ $300 \mathrm{~s}$, amounting to a total imaging time of $60 \mathrm{~min}$. Twenty-four hours later, the same mice were injected with $100 \mu \mathrm{L}$ of Gelofusine $(40 \mathrm{mg}$ / $\mathrm{mL}$ ) and $100 \mathrm{pmol} / 0.6-0.8 \mathrm{MBq} / 100 \mu \mathrm{L}$ of ${ }^{68} \mathrm{Ga}-\mathrm{EG} 4$, and dynamic imaging was performed as described above. Immediately after the end of the dynamic scans, the mice were sacrificed and underwent nephrectomy, and static imaging was performed for $30 \mathrm{~min}$. For the second group, on day 1 the mice were administered $150 \mu \mathrm{L}$ of vildagliptin by oral gavage $(10 \mu \mathrm{mol} / \mathrm{kg})$. One hour later, intravenous injection of $100 \mathrm{pmol} / 0.6-0.8 \mathrm{MBq} / 100 \mu \mathrm{L}$ of ${ }^{68} \mathrm{Ga}-\mathrm{EG} 4$ followed and dynamic imaging was performed as above. The day after, the same mice $1 \mathrm{~h}$ after oral administration of vildagliptin $(10 \mu \mathrm{mol} / \mathrm{kg})$ were injected with $100 \mu \mathrm{L}$ of Gelofusine $(40 \mathrm{mg} / \mathrm{mL})$ and $100 \mathrm{pmol} / 0.6-0.8 \mathrm{MBq} / 100 \mu \mathrm{L}$ of ${ }^{68} \mathrm{Ga}-\mathrm{EG} 4$, followed by dynamic imaging. Blocking experiments were performed as described above, and dynamic scans were obtained for $60 \mathrm{~min}$ following the same acquisition frames.

PET images were corrected for ${ }^{68} \mathrm{Ga}$ decay and reconstructed with filtered backprojection. No correction was applied for attenuation. Images were generated using AMIDE software.

\section{Statistical Analysis}

All data are expressed as the mean \pm SD. Prism 5 software (GraphPad Software) was used to determine statistical significance at the $95 \%$ confidence level, with a $P$ value of less than 0.05 being considered significantly different.

\section{RESULTS}

\section{Peptides and Radiolabeling}

The EG1, EG2, and EG4 GIP ligands were custom-synthesized according to the solid-phase peptide synthesis method by Peptide Specialty Laboratories GmbH. The analytic data of the purified conjugates are reported in Table 1 and in the supplemental material.

The labeling yields for ${ }^{111} \mathrm{In}$-conjugates were more than $95 \%$ at a specific activity of $7-8 \mathrm{GBq} / \mu \mathrm{mol}$. The GIP conjugates were labeled with ${ }^{68} \mathrm{Ga}$ with a labeling yield of more than $98 \%$ and a specific activity ranging between 20 and $25 \mathrm{GBq} / \mu \mathrm{mol}$.

\section{Binding Affinities}

Compared with the reference peptide $\operatorname{GIP}(1-30)\left(\mathrm{IC}_{50}, 1.3 \pm\right.$ $0.6 \mathrm{nM}), \mathrm{EG} 1, \mathrm{EG} 2$, and EG4 retained high affinity to human GIP

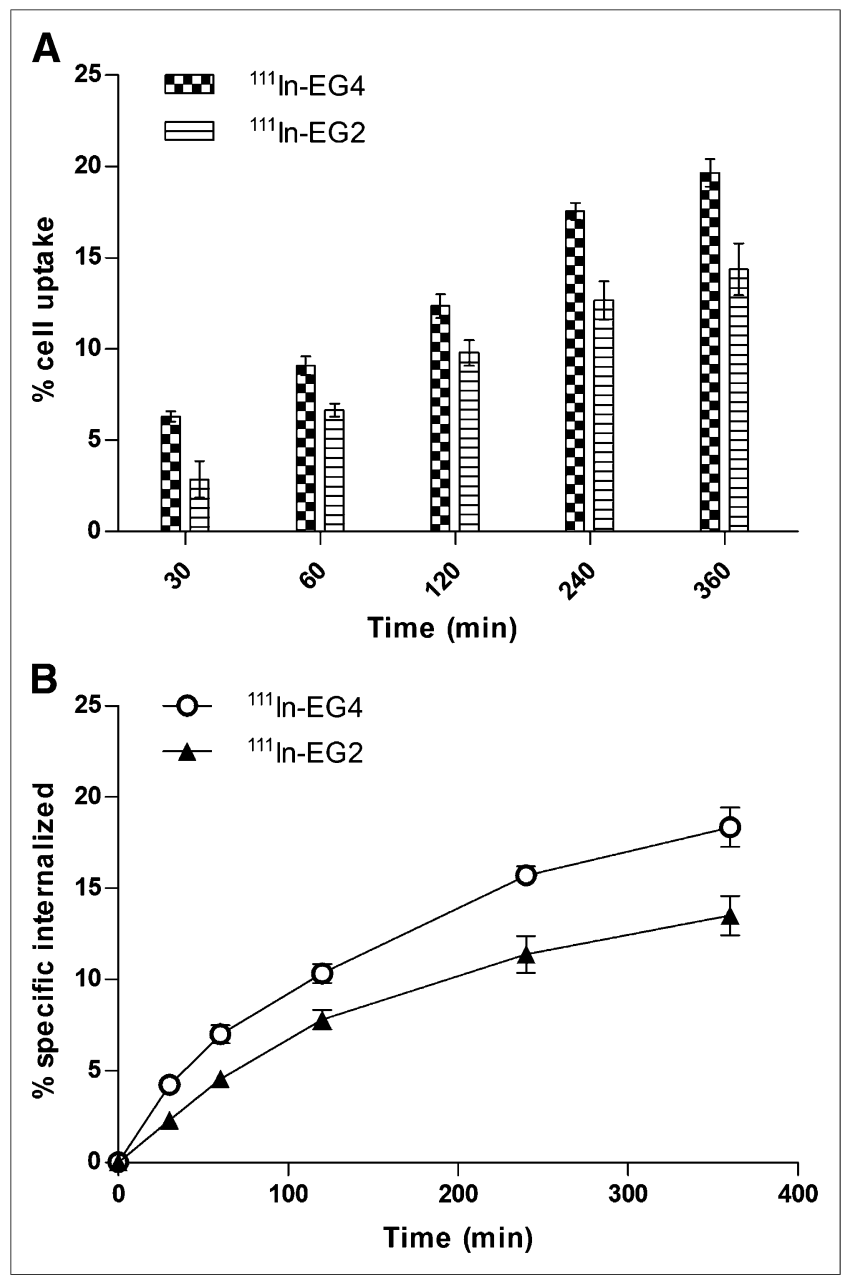

FIGURE 2. Specific cell uptake and internalization rate after incubation of INR1 G9-hGIPr cells with ${ }^{111} \mathrm{In}$-EG2 and ${ }^{111} \mathrm{In}$-EG4 for $6 \mathrm{~h}$ at $37^{\circ} \mathrm{C}$. (A) Cell uptake calculated as cell surface-bound and internalized fraction. (B) Receptor-specific internalization expressed as percentage of applied radioactivity. Nonspecific binding was determined in presence of $1 \mu \mathrm{M}$ GIP(1-30). 
receptor $\left(\mathrm{IC}_{50}: 2.1 \pm 1.0,2.5 \pm 0.8\right.$, and $1.5 \pm 0.7 \mathrm{nM}$, respectively) (Table 1; Supplemental Fig. 1).

\section{Saturation Binding and Internalization Studies}

Saturation binding studies were performed at $4^{\circ} \mathrm{C}$, to allow binding of the radioconjugates to the receptor but to avoid endocytosis. Both 111/natIn-EG2 and 111/natIn-EG4 exhibited similar affinity for the INR1G9-hGIP, with $\mathrm{K}_{\mathrm{d}}$ values of $10.6 \pm 1.6 \mathrm{nM}$

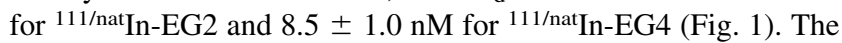
$\mathrm{B}_{\max }$ values were also at the same level for both conjugates $(0.7 \pm$

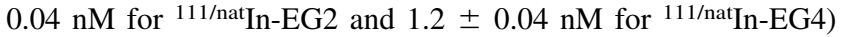
and corresponded to approximately $6 \times 10^{5}$ receptors per cell (supplemental material).

Both ${ }^{111}$ In-labeled GIP ligands were well associated with the INR1G9-hGIPr cells within the 6-h incubation (Fig. 2). Continued exposure of the cells to the radioligands resulted in a gradual increase in the total cell-associated uptake from $30 \mathrm{~min}$ to $6 \mathrm{~h}$, which was slightly higher for ${ }^{111}$ In-EG4 $(19.7 \% \pm 0.8 \%)$ than for ${ }^{111}$ InEG2 $(14.4 \% \pm 1.4 \%)$ at $6 \mathrm{~h}(P=0.0035)$. The internalized fraction increased with time from $30 \mathrm{~min}$ to $6 \mathrm{~h}$, and at $6 \mathrm{~h}$ the internalization rate was somewhat higher for ${ }^{111}$ In-EG4 $(18.3 \% \pm$ $1.1 \%)$ than for ${ }^{111}$ In-EG2 $(13.5 \% \pm 1.1 \%)(P=0.0054)$. Almost the entire cell-associated activity was internalized in both cases, supporting their agonist potency. Blocking experiments performed with an excess of GIP(1-30) showed negligible nonspecific binding on the cell surface, whereas less than $0.3 \%$ of total added radioactivity was found to be internalized (data not shown), demonstrating the high specificity of the GIP conjugates toward INR1G9-hGIPr cells.

\section{Biodistribution and Renal Uptake Reduction Studies}

Both ${ }^{111} \mathrm{In}-\mathrm{EG} 4$ and ${ }^{68} \mathrm{Ga}-\mathrm{EG} 4$ showed fast blood clearance, with $0.04 \% \mathrm{IA} / \mathrm{g}$ remaining in the blood at $4 \mathrm{~h}$ after injection of ${ }^{111} \mathrm{In}-\mathrm{EG} 4$ and $0.03 \% \mathrm{IA} / \mathrm{g}$ at $2 \mathrm{~h}$ after injection of ${ }^{68} \mathrm{Ga}-\mathrm{EG} 4$, resulting in high tumor-to-blood ratios. ${ }^{111} \mathrm{In}-\mathrm{EG} 4$ and ${ }^{68} \mathrm{Ga}-\mathrm{EG} 4$ specifically targeted INR1G9-hGIPr xenografts. The tumor had the highest uptake-10.4 \pm 2.2 and $17.0 \pm 4.4 \% \mathrm{IA} / \mathrm{g}$, respectively $-1 \mathrm{~h}$ after injection, and uptake dropped to $2.0 \pm 0.2$ and
$1.3 \pm 0.3 \% \mathrm{IA} / \mathrm{g} 1 \mathrm{~h}$ after injection when a 2,000-times excess of GIP(1-30) was preinjected (Tables 2 and 3).

Kidney uptake was high and persistent for both ${ }^{111} \mathrm{In}-\mathrm{EG} 4$ and ${ }^{68} \mathrm{Ga}-\mathrm{EG} 4$, reaching values greater than $200 \% \mathrm{IA} / \mathrm{g}$. In separated groups of mice ( $n=4 /$ group), $100 \mu \mathrm{L}(40 \mathrm{mg} / \mathrm{mL}$ ) of Gelofusine or $150 \mu \mathrm{L}(10 \mu \mathrm{mol} / \mathrm{kg})$ of vildagliptin were administered before the injection of the radiopeptides followed by biodistribution studies at $1 \mathrm{~h}$ after injection (Tables 2 and 3). The administration of Gelofusine reduced kidney uptake by about $40 \%\left(32 \%\right.$ for ${ }^{68} \mathrm{Ga}-$ EG4 $[P=0.035]$ and $42 \%$ for ${ }^{111}$ In-EG4 $\left.[P=0.034]\right)$ without significantly affecting the overall biodistribution profile. Similarly, when vildagliptin was administered, kidney uptake was reduced by a factor of about 2, leading to a tumor-to-kidney ratio of 0.09 . The combination of Gelofusine and vildagliptin did not cause a further reduction of kidney uptake $(P<0.05)$ (Supplemental Table 2).

\section{Small-Animal PET Studies}

Representative PET images of INR1G9-hGIPr mice on injection of ${ }^{68} \mathrm{Ga}-\mathrm{EG} 4$ were obtained (Fig. 3). Specific tumor uptake was visualized within the 60 -min time frame; the initial background uptake of ${ }^{68} \mathrm{Ga}-\mathrm{EG} 4$ in the excretion organs (kidneys) rapidly increased over time. These images well represented the results from the biodistribution studies and particularly the reduction of kidney uptake after administration of Gelofusine or vildagliptin. Furthermore, the nephrectomy allowed better visualization of the abdominal organs that were overlapped by the high kidney uptake. Urinary excretion of the tracer was represented by the high focal activity concentration in the urinary bladder at all time points.

\section{DISCUSSION}

Despite almost $30 \mathrm{y}$ of intense research on the development of radiopeptides, only the targeting of NETs has a real impact on patient care (7), because of the high expression of somatostatin and GLP-1 receptors (1). Unfortunately, the lack of somatostatin or GLP-1 receptor in specific NETs, such as insulinomas, demands the identification of a new family of receptors that qualifies for

TABLE 2

Biodistribution Data and Tissue Radioactivity Ratios of ${ }^{111}$ In-EG4 in INR1G9-hGIPr Xenografts

\begin{tabular}{|c|c|c|c|c|c|}
\hline Organ & $1 \mathrm{~h}$ & $1 \mathrm{~h}$ blocked & 1 h/Gelofusine & $4 \mathrm{~h}$ & $24 \mathrm{~h}$ \\
\hline Blood & $0.4 \pm 0.1$ & $0.6 \pm 0.02$ & $0.5 \pm 0.1$ & $0.04 \pm 0.01$ & $0.01 \pm 0.00$ \\
\hline Heart & $0.2 \pm 0.03$ & $0.3 \pm 0.06$ & $0.3 \pm 0.13$ & $0.1 \pm 0.02$ & $0.1 \pm 0.03$ \\
\hline Liver & $2.0 \pm 0.5$ & $2.7 \pm 0.7$ & $2.6 \pm 0.6$ & $1.6 \pm 0.1$ & $2.2 \pm 0.3$ \\
\hline Spleen & $3.6 \pm 0.9$ & $4.5 \pm 0.6$ & $4.6 \pm 0.5$ & $2.5 \pm 0.4$ & Not determined \\
\hline Lung & $7.8 \pm 0.9$ & $13.1 \pm 3.0$ & $7.2 \pm 1.4$ & $2.0 \pm 0.7$ & $0.9 \pm 0.3$ \\
\hline Kidney & $217 \pm 39$ & $209 \pm 17$ & $125 \pm 5$ & $205 \pm 34$ & $173 \pm 28$ \\
\hline Stomach & $0.6 \pm 0.1$ & $0.7 \pm 0.1$ & $0.7 \pm 0.2$ & $0.3 \pm 0.06$ & $0.3 \pm 0.04$ \\
\hline Intestine & $0.5 \pm 0.2$ & $1.0 \pm 0.07$ & $1.4 \pm 0.4$ & $0.5 \pm 0.6$ & $0.2 \pm 0.03$ \\
\hline Adrenal & $1.5 \pm 0.8$ & $0.6 \pm 0.5$ & $1.4 \pm 0.4$ & $1.9 \pm 1.5$ & $0.7 \pm 0.2$ \\
\hline Pancreas & $0.2 \pm 0.06$ & $0.2 \pm 0.04$ & $0.2 \pm 0.06$ & $0.1 \pm 0.01$ & $0.06 \pm 0.03$ \\
\hline Muscle & $0.2 \pm 0.04$ & $0.1 \pm 0.05$ & $0.3 \pm 0.16$ & $0.1 \pm 0.06$ & $0.06 \pm 0.03$ \\
\hline Bone & $0.4 \pm 0.08$ & $0.3 \pm 0.04$ & $0.8 \pm 0.45$ & $0.3 \pm 0.06$ & $0.3 \pm 0.3$ \\
\hline INR1G9 tumor & $10.4 \pm 2.2$ & $2.0 \pm 0.2$ & $9.2 \pm 0.7$ & $6.6 \pm 1.3$ & $3.6 \pm 0.7$ \\
\hline Tumor/blood & $28 \pm 9$ & & $21 \pm 6$ & $156 \pm 22$ & $320 \pm 51$ \\
\hline Tumor/lung & $1.2 \pm 0.03$ & & $1.3 \pm 0.2$ & $2.4 \pm 0.9$ & $3.1 \pm 1.2$ \\
\hline Tumor/kidney & $0.05 \pm 0.01$ & & $0.07 \pm 0.01$ & $0.03 \pm 0.00$ & $0.02 \pm 0.01$ \\
\hline Tumor/muscle & $64 \pm 14$ & & $32 \pm 17$ & $54 \pm 19.31$ & $68 \pm 32$ \\
\hline
\end{tabular}

Data are presented as mean $\pm \mathrm{SD}(n=4) \% \mathrm{IA} / \mathrm{g}$ of tissue; blocking studies were performed in presence of $20 \mathrm{nmol}$ of $\mathrm{GIP}(1-30)$. 
TABLE 3

Biodistribution Data and Tissue Radioactivity Ratios of ${ }^{68}$ Ga-EG4 in INR1G9-hGIPr Xenografts

\begin{tabular}{|c|c|c|c|c|c|}
\hline Organ & $1 \mathrm{~h}$ & $1 \mathrm{~h}$ blocked & 1 h/Gelofusine & $1 \mathrm{~h} /$ vildagliptin & $2 \mathrm{~h}$ \\
\hline Blood & $0.6 \pm 0.1$ & $0.6 \pm 0.2$ & $1.4 \pm 0.4$ & $0.4 \pm 0.2$ & $0.03 \pm 0.02$ \\
\hline Heart & $0.1 \pm 0.03$ & $0.05 \pm 0.3$ & $0.6 \pm 0.01$ & $0.2 \pm 0.1$ & $0.03 \pm 0.02$ \\
\hline Liver & $3.3 \pm 0.6$ & $2.0 \pm 0.5$ & $4.6 \pm 2.8$ & $2.8 \pm 0.6$ & $3.1 \pm 1.3$ \\
\hline Spleen & $5.2 \pm 2.3$ & $2.9 \pm 0.2$ & $4.6 \pm 1.5$ & $5.4 \pm 1.1$ & $5.9 \pm 3.9$ \\
\hline Lung & $5.5 \pm 2.3$ & $2.9 \pm 0.3$ & $5.0 \pm 0.3$ & $6.9 \pm 3.8$ & $6.6 \pm 3.9$ \\
\hline Kidney & $283 \pm 25$ & $281 \pm 48$ & $191 \pm 32$ & $152 \pm 24$ & $295 \pm 33$ \\
\hline Stomach & $1.3 \pm 0.8$ & $0.6 \pm 0.16$ & $1.2 \pm 0.8$ & $0.7 \pm 0.6$ & $0.05 \pm 0.02$ \\
\hline Intestine & $1.1 \pm 0.6$ & $1.1 \pm 0.1$ & $0.8 \pm 0.5$ & $0.7 \pm 0.3$ & $0.4 \pm 0.04$ \\
\hline Adrenal glands & $0.01 \pm 0.00$ & $1.4 \pm 0.7$ & $0.00 \pm 0.00$ & $1.2 \pm 0.8$ & $0.01 \pm 0.00$ \\
\hline Pancreas & $0.7 \pm 0.5$ & $0.2 \pm 0.06$ & $0.08 \pm 0.01$ & $0.4 \pm 0.3$ & $0.04 \pm 0.01$ \\
\hline Muscle & $0.07 \pm 0.03$ & $0.05 \pm 0.01$ & $0.05 \pm 0.01$ & $0.07 \pm 0.02$ & $0.01 \pm 0.00$ \\
\hline Bone & $0.3 \pm 0.5$ & $1.5 \pm 0.6$ & $0.01 \pm 0.00$ & $1.0 \pm 0.5$ & $0.07 \pm 0.02$ \\
\hline INR1G9 tumor & $17.0 \pm 4.4$ & $1.3 \pm 0.3$ & $15.8 \pm 5.4$ & $13.4 \pm 3.8$ & $6.8 \pm 1.1$ \\
\hline Tumor/blood & $35 \pm 4$ & & $12 \pm 8$ & $23 \pm 2$ & $233 \pm 77$ \\
\hline Tumor/lung & $4 \pm 1.5$ & & $2.4 \pm 1$ & $2.3 \pm 1.9$ & $1.1 \pm 0.6$ \\
\hline Tumor/kidney & $0.05 \pm 0.01$ & & $0.07 \pm 0.06$ & $0.09 \pm 0.04$ & $0.02 \pm 0.01$ \\
\hline Tumor/muscle & $291 \pm 68$ & & $276 \pm 37$ & $219 \pm 47$ & $677 \pm 106$ \\
\hline
\end{tabular}

Data are presented as mean $\pm \mathrm{SD}(n=4) \% \mathrm{IA} / \mathrm{g}$ of tissue; blocking studies were performed in presence of $20 \mathrm{nmol}$ of $\mathrm{GIP}(1-30)$.

successful in vivo targeting of those tumors (20). In vitro autoradiography studies on tumor tissues from surgical specimens, evaluating the expression of GIP receptor versus somatostatin receptor, have shown that GIP receptor is overexpressed in a given number of samples originating from pancreatic NETs whereas only about $65 \%$ of the same samples were found to be positive for somatostatin receptor. Of 24 bronchial NETs, 22 were positive for GIP receptor but only 12 for somatostatin receptor (20). The fact that most of these tumors retain the GIP receptor even when they lack the somatostatin receptor paves the way for targeting a broader spectrum of NETs. Consequently, the importance of the overexpression of GIP receptor in NETs relies on 2 major advantages: first, the NETs that lack the somatostatin or GLP-1 receptor but retain the GIP receptor may be integrated into the successful peptide receptor targeting method. Furthermore, the simultaneous coexistence of GIP receptor with somatostatin or even GLP-1 receptor in a large number of NETs might argue for multiple receptor targeting using a cocktail of radioligands (8).

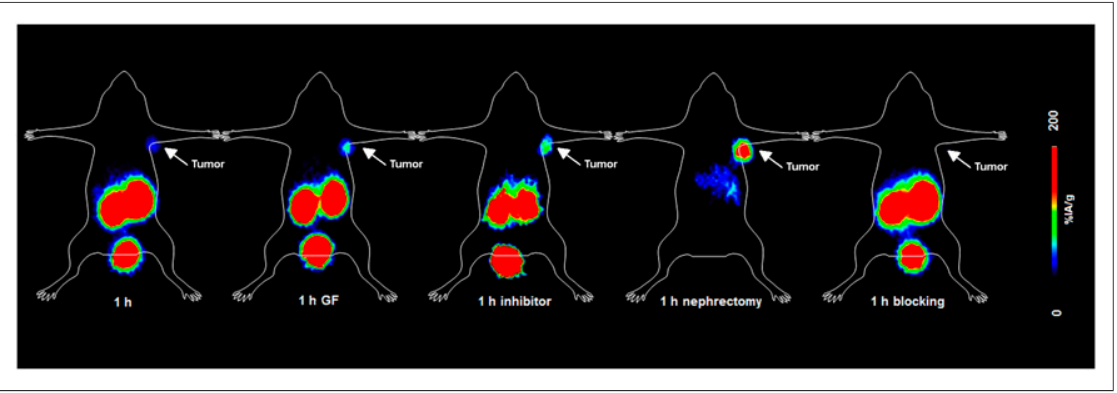

FIGURE 3. PET dynamic imaging of INR1G9-hGIPR tumor-bearing mice on injection of ${ }^{88} \mathrm{Ga}$ EG4 at $1 \mathrm{~h}$ after injection along with blocking studies. Images clearly visualized tumor and proved the specificity of the radiopeptide; kidney uptake was high. After administration of Gelofusine or vildagliptin, kidney uptake was lower, resulting in better delineation of tumor. After bilateral nephrectomy, $1 \mathrm{~h}$ after injection, uptake in abdomen was distinguishable from tumor with weak signal.
In this frame, we developed and evaluated a new class of radioligands with the potential to be used for the in vivo targeting of GIP receptor-positive tumors. Because the truncated peptide GIP(1-30) activates the GIP receptor as efficiently as the fulllength peptide GIP(1-42) (25), the GIP(1-30) was chosen as the peptide motif of our study. The peptide was functionalized with the chelator DOTA via 6-Ahx coupled to the side chains of Lys ${ }^{16}$ and $\mathrm{Lys}^{30}$, respectively, to obtain EG1, EG2, and EG4. In EG4, the $\mathrm{Met}^{14}$ was substituted with Nle, as a widely used strategy for stabilizing peptides against oxidative damage and allowing easier handling. The GIP conjugates were labeled with ${ }^{68} \mathrm{Ga}$ and ${ }^{111} \mathrm{In}$. Because of its availability from generator systems and the relative ease of labeling chemistry, the positron emitter ${ }^{68} \mathrm{Ga}$ has gained increasing interest in the field of molecular imaging with PET (28). On the other hand, ${ }^{111} \mathrm{In}$ is being used as an important SPECT label and as a surrogate of $\beta$ emitters such as ${ }^{90} \mathrm{Y}$.

The coupling of Ahx-DOTA to Lys side chains of GIP(1-30) independently of the site of modification does not influence the binding affinity of the conjugates toward GIP receptor. The substitution of $\mathrm{Met}^{14}$ with Nle improved the affinity of EG4 about 1.5-fold compared with EG1. Furthermore, saturation binding studies exhibited high and comparable affinities for both 111/natIn-EG2 and 111/natIn-EG4, with $\mathrm{K}_{\mathrm{d}}$ values in the low nanomolar range.

The further in vitro evaluation showed comparable cellular uptake of the ${ }^{111}$ Inlabeled radiopeptides, with ${ }^{111}$ In-EG4 exhibiting a somewhat superior profile. In both cases, more than $90 \%$ of the total cell-associated activity was internalized into the cancer cells. The almost identical affinity of the DOTA conjugates in comparison to the parent agonist GIP(1-30) and the efficient receptor-mediated internalization led us to conclude that EGs are agonists $(25,29)$. 
We further proceeded with the in vivo evaluation of the most promising candidate, EG4, aiming at the development of a proofof-principle radioligand that leads to feasible imaging of GIP receptor-positive tumors. Biodistribution studies of ${ }^{111} \mathrm{In}-\mathrm{EG} 4$ and ${ }^{68} \mathrm{Ga}$-EG4 showed fast blood clearance and specific targeting of INR1G9-hGIPr xenografts. The washout from the tumor is not yet understood and is contrary to the GLP-1 receptor-targeting radiopeptides, which impress by a long tumor retention time $(12,13)$. The kidneys showed the highest uptake, which remained high at all tested time points. Similar kidney uptake was reported for $\left[\mathrm{Lys}^{40}\left(\mathrm{Ahx}-\mathrm{DTPA}-{ }^{111} \mathrm{In}\right) \mathrm{NH}_{2}\right]$ exendin-4, $\left[\mathrm{Lys}^{40}\left(\mathrm{Ahx}-\mathrm{DOTA}-{ }^{111} \mathrm{In}\right)\right.$ $\mathrm{NH}_{2}$ ] exendin-4, and [Lys ${ }^{40}$ (DOTA)] exendin-3 labeled either with ${ }^{111} \mathrm{In}$ or ${ }^{68} \mathrm{Ga}(12-14)$. Uptake of radiolabeled peptides in kidneys is a major problem because of the nephrotoxicity caused by the accumulated activity. This problem is even more pronounced if therapeutic applications are planned (30). The rationale for using Gelofusine as a reuptake blocking agent relies on the fact that the metallated DOTA-conjugated peptides contain $3 \mathrm{Asp}, 1 \mathrm{Glu}$, and 1 Lys, having 3 negative charges at physiologic $\mathrm{pH}$, Gelofusine is a succinylated gelatin with a net negative surface charge. Indeed, the administration of Gelofusine led to a reduction of kidney uptake by about $40 \%$. One additional major parameter that needs to be considered is the high GIP peptide cleavage rate by DPP-4. Natural or synthetic regulatory peptides that possess at the $\mathrm{N}$-terminus penultimate position a proline or alanine residue have proved to be good substrates for DPP-4 (30). Especially, for GIP, the minimal N-terminal truncation by DPP-4 leads to full inactivation of the truncated peptide GIP(3-42) (25). DPP-4 can be detected in most organs, such as the kidneys, liver, pancreas, and intestine; high activity was found in the kidneys, in which the enzyme is mostly localized in the brush-border and microvillus fractions. Indeed, Deacon et al. have shown that DPP-4 inhibition significantly reduces renal clearance, most probably because GIP degradation by DPP-4 takes place in the renal capillary endothelium (31). On the basis of these findings and in an attempt to increase the metabolic stability that should lead to higher tumor uptake or longer retention, and to further reduce the accumulated activity in the kidneys, we investigated the influence of the clinically used DPP-4 inhibitor, vildagliptin (32). Biodistribution studies showed a 2-fold reduction in kidney uptake compared with the control group of mice, leading to an improved tumor-to-kidney ratio. Surprisingly, the administration of vildagliptin did not affect tumor uptake, but the lower kidney uptake led to higher PET contrast.

Despite the high kidney uptake, PET imaging studies proved that delineation of the tumor is feasible. Higher contrast was achieved after the administration of Gelofusine or vildagliptin. At a high threshold level after bilateral nephrectomy, uptake in the abdomen was distinguishable from tumor, with a weak signal.

\section{CONCLUSION}

The preclinical evaluation of ${ }^{111} \mathrm{In}$ - and ${ }^{68} \mathrm{Ga}$-labeled EG4 as proof-of-principle radioligands indicated that diagnostic imaging of GIP receptor-positive tumors is feasible. Coupling of GIP(130) to a DOTA chelator leads to GIP receptor-specific ligands able to be used for PET or SPECT imaging. Despite kidney uptake, which could be reduced by approximately $40 \%-50 \%$ either by Gelofusine or vildagliptin, these results prompt us to further continue the development of this family of radioligands that allows the imaging of a broad spectrum of NETs.

\section{DISCLOSURE}

The costs of publication of this article were defrayed in part by the payment of page charges. Therefore, and solely to indicate this fact, this article is hereby marked "advertisement" in accordance with 18 USC section 1734 . This work was supported by the German Consortium for Translational Cancer Research (DKTK) and Région Midi-Pyrénées, France. No other potential conflict of interest relevant to this article was reported.

\section{ACKNOWLEDGMENTS}

We thank Roswitha Toennesmann and Yvonne Kiefer for technical assistance and Véronique Gigoux for help in INR1G9hGIPr cloning.

\section{REFERENCES}

1. Fani M, Maecke HR. Radiopharmaceutical development of radiolabelled peptides. Eur J Nucl Med Mol Imaging. 2012;39(suppl 1):S11-S30.

2. Schottelius M, Wester HJ. Molecular imaging targeting peptide receptors. Methods. 2009;48:161-177.

3. Gibril F, Reynolds JC, Doppman JL, et al. Somatostatin receptor scintigraphy: its sensitivity compared with that of other imaging methods in detecting primary and metastatic gastrinomas-a prospective study. Ann Intern Med. 1996;125: 26-34.

4. Imhof A, Brunner P, Marincek N, et al. Response, survival, and long-term toxicity after therapy with the radiolabeled somatostatin analogue $\left[{ }^{90} \mathrm{Y}\right.$ DOTA]-TOC in metastasized neuroendocrine cancers. J Clin Oncol. 2011;29: 2416-2423.

5. Kwekkeboom DJ, Bakker WH, Kam BL, et al. Treatment of patients with gastropancreatic (GEP) tumors with the novel radiolabeled somatostatin analogue $\left[{ }^{177}\right.$ Lu-DOTA $^{0}$, Tyr $\left.^{3}\right]$ octreotate. Eur J Nucl Med Mol Imaging. 2003;30:417422.

6. Wild D, Schmitt JS, Ginj M, et al. DOTA-NOC, a high affinity ligand of somatostatin receptor subtypes 2, 3 and 5 for labeling with various radiometals. Eur J Nucl Med Mol Imaging. 2003;30:1338-1347.

7. Maecke HR, Reubi JC. Somatostatin receptors as targets for nuclear medicine imaging and radionuclide treatment. J Nucl Med. 2011;52:841-844.

8. Reubi JC, Waser B. Concomitant expression of several peptide receptors in neuroendocrine tumors as molecular basis for in vivo multireceptor tumor targeting. Eur J Nucl Med Mol Imaging. 2003;30:781-793.

9. Reubi JC. Peptide receptor expression in GEP-NET. Virchows Arch. 2007;451 (suppl 1):S47-S50.

10. Körner M, Stockli M, Waser B, Reubi JC. GLP-1 receptor expression in human tumors and human normal tissues: potential for in vivo targeting. $\mathrm{J} \mathrm{Nucl} \mathrm{Med}$. 2007; 48:736-743.

11. Reubi JC. Old and new peptide receptor targets in cancer: future directions. Recent Results Cancer Res. 2013;194:567-576.

12. Wild D, Béhé M, Wicki A, et al. [Lys ${ }^{40}\left(\right.$ Ahx-DTPA- $\left.{ }^{111} \mathrm{In}\right) \mathrm{NH}_{2}$ ] exendin-4, a very promising ligand for glucagon-like peptide-1 (GLP-1) receptor targeting. J Nucl Med. 2006;47:2025-2033.

13. Wild D, Wicki A, Mansi R, et al. Exendin-4-based radiopharmaceuticals for glucagon-like peptide-1 receptor PET/CT and SPECT/CT. J Nucl Med. 2010; 51:1059-1067.

14. Brom M, Oyen WJ, Joosten L, Gotthardt M, Boerman OC. ${ }^{68}$ Ga-labeled exendin-3, a new agent for the detection of insulinomas with PET. Eur J Nucl Med Mol Imaging. 2010;37:1345-1355.

15. Gotthardt M, Fischer M, Naeher I, et al. Use of the incretin hormone glucagonlike peptide-1 (GLP-1) for the detections of insulinomas: initial experimental results. Eur J Nucl Med Mol Imaging. 2002;29:597-606.

16. Murage EN, Gao H, Bisello A, Ahn JM. Development of potent glucagon-like peptide-1 agonists with high enzyme stability via introduction of multiple lactam bridges. J Med Chem. 2010;53:6412-6420.

17. Kiesewetter DO, Gao H, Ma Y, et al. ${ }^{18} \mathrm{~F}$-radiolabeled analogs of exendin-4 for PET imaging of GLP-1 in insulinoma. Eur J Nucl Med Mol Imaging. 2012;39: 463-473.

18. Wild D, Maecke HR, Christ E, Gloor B, Reubi JC. Glucagon-like peptide-1 receptor scans to localize occult insulinomas. N Engl J Med. 2008;359:766768. 
19. Christ E, Wild D, Forrer F, et al. Glucagon-like peptide-1 receptor imaging for localization of insulinomas. J Clin Endocrinol Metab. 2009;94: 4398-4405.

20. Waser B, Rehmann R, Sanchez C, Fourmy D, Reubi JC. Glucose-dependent insulinotropic polypeptide receptors in most gastroenteropancreatic and bronchial neuroendocrine tumors. J Clin Endocrinol Metab. 2012;97:482-488.

21. Brubaker PL, Drucker DJ. Structure-function of the glucagon receptor family of the G protein-coupled receptors: the glucagon, GIP, GLP-1, and GLP-2 receptors. Receptors Channels. 2002;8:179-188.

22. McIntosh $\mathrm{CH}$, Widenmaier S, Kim SJ. Glucose-dependent insulinotropic polypeptide (gastric inhibitory polypeptide; GIP). Vitam Horm. 2009;80:409-471.

23. Mentlein R. Dipeptidyl-peptidase IV (CD26): role in the inactivation of regulatory peptides. Regul Pept. 1999;85:9-24.

24. Mentlein R. Mechanisms underlying the rapid degradation and elimination of the incretin hormones GLP-1 and GIP. Best Pract Res Clin Endocrinol Metab. 2009;23:443-452.

25. Yaqub T, Tikhonova IG, Lättig J, et al. Identification of the determinants of glucose-dependent insulinotropic polypeptide receptor that interact with N-terminal biologically active region of the natural ligand. Mol Pharmacol. 2010;77:547558.
26. Moon MJ, Kim HY, Kim SG, et al. Tyr ${ }^{1}$ and Ile ${ }^{7}$ of glucose-dependent insulinotropic polypeptide (GIP) confer differential ligand selectivity toward GIP and glucagon-like peptide-1 receptors. Mol Cells. 2010;30:149-154.

27. Parthier C, Kleinsschmidt M, Neumann P, et al. Crystal structure of the incretinbound extracellular domain of a G protein-coupled receptor. Proc Natl Acad Sci USA. 2007;104:13942-13947.

28. Maecke HR, Hofmann M, Haberkorn U. ${ }^{68} \mathrm{Ga}$-labeled peptides in tumor imaging. J Nucl Med. 2005;46(suppl 1):172S-178S.

29. Hinke SA, Manhart S, Pamir N, et al. Identification of bioactive domain in the amino-terminus of glucose-dependent insulinotropic polypeptide (GIP). Biochim Biophys Acta. 2001;1547:143-155.

30. Gotthardt M, Eerd-Vismale J, Oyen WJG, et al. Indication for different mechanisms of kidney uptake of radiolabeled peptides. J Nucl Med. 2007; 48:596-601.

31. Deacon CF, Danielsen P, Klarskov L, Olesen M, Holst JJ. Dipeptidyl peptidase IV inhibitor reduces the degradation and clearance of GIP and potentiates its insulinotropic and antihyperglycemic effects in anesthetized pigs. Diabetes. 2001;50:1588-1597.

32. Barnett A. DPP-4 inhibitors and their potential role in the management of type 2 diabetes. Int J Clin Pract. 2006;60:1454-1470. 